Resona Jurnal I miah Pengabdian Masyarakat Vol. 1, No. 1 (2017) 6-12

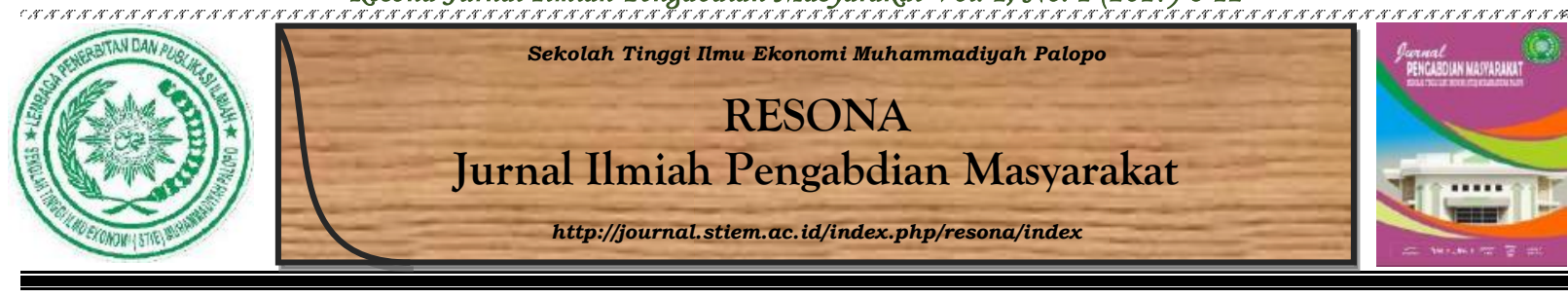

\title{
KKN-PPM Penguatan Ekonomi Desa melalui BUMDES di Desa Poreang Kecamatan Tana Lili Kabupaten Luwu Utara Sulawesi Selatan
}

Suhardi M. Anwar ${ }^{1}$, Goso ${ }^{2}$, Adil ${ }^{3}$

1,2,3 Sekolah Tinggi Ilmu Ekonomi Muhammadiyah Palopo

\author{
INFO NASKAH

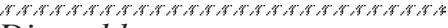 \\ Diserahkan \\ 30 November 2017 \\ Diterima dan disetujui \\ 26 Desember 2017

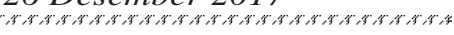

\section{Kata Kunci:}

Penguatan ekonomi

Bumdes

Pemberdayaan

Masyarakat

Desa

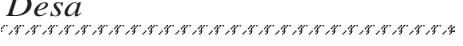

\begin{abstract}
ABSTRAK Membangun kekuatan ekonomi desa hanya bisa dilakukan dengan menyejahterakan masyarakat melalui program pemberdayaan dan kemandirian masyarakat dalam kehidupan ekonominya. Tujuan pembangunan otonomi asli desa adalah mengembangkan prakarsa dari dalam (inward looking) dan menumbuhkan kekuatan-kekuatan baru masyarakat. Pada hakikatnya masyarakat dapat berkembang sesuai dengan potensi yang dimilikinya. Usaha pemberdayaan masyarakat mensyaratkan keterlibatan masyarakat. Hal ini dimaksudkan supaya menjadi subyek proses perencanaan dan mampu berkembang secara mandiri serta keberlanjutan sebagai unit sosial maupun unit ekonomi yang otonom. Kelembagaan yang mengakar pada masyarakat Desa Poreang, Kecamatan Tana Lili, belum mampu berkembang, baik ditinjau dari aspek ekonomi maupun aspek sosial. Pemberdayaan dilakukan dengan participatory rural appraisal (PRA) bersinergi dengan melibatkan mahasiswa yang memprogramkan KKN-PPM. Hasil yang dicapai dari program pemberdayaan ini adalah meningkatnya kapasitas pengelolaan pembangunan khususnya penguatan ekonomi masyarakat melalui peran Bumdes dalam memberdayakan masyarakat di berbagai sektor usaha yang telah dibentuk serta dengan program sarasehan, seminar, dan pelatihan masyarakat Desa Poreang telah memiliki kemampuan mengantisipasi perubahan lingkungan makro.
\end{abstract}

\section{Pendahuluan}

Kesejahteraan masyarakat hanya mungkin diupayakan dengan memberdayakan dan memandiriakan masyarakat dalam kehidupan ekonominya. Hal ini dilakukan dengan membangun daya dan tenaga yang dimiliki masyarakat melalui motivasi untuk membangkitkan kesadaran masyarakat akan potensi yang dimiliki serta berusaha untuk bisa

\footnotetext{
Corresponding Author:

1 suhardi@stiem.ac.id, manwarsuhardi@gmail.com; +62 81343513111

2 goso@stiem.ac.id; +62 81343798848

3 adil_basyr14@yahoo.com; +62 85335219859
} 
mengembangkan potensi yang ada dalam kehidupan. Sejalan dengan diberlakukannya UU Nomor 22 dan UU Nomor 25 tahun 1999 dan sejak awal 2001, telah mampu memberikan pengembangan terhadap pembangunan dan perkembangan daerah, terutama dalam kewenangan yang luas dalam mengelola potensi sumberdaya yang tersedia dengan seoptimal mungkin sebagai upaya dalam memprioritaskan pembangunan di daerah yang berbasiskan pada pengembangan masyarakat sesuai dengan kondisi sosial budaya setempat.

Pada hakikatnya masyarakat dapat berkembang sesuai dengan potensi yang dimilikinya. Oleh karena itu, usaha pemberdayaan masyarakat menyaratkan keterlibatan masyarakat mulai dari perencanaan, pelaksanaan, maupun pada saat monitoring dan evaluasi. Hal ini dimaksudkan supaya menjadi subyek proses perencanaan dan mampu berkembang secara mandiri, keberlanjutan sebagai unit sosial maupun ekonomi yang otonom.

Potensi yang dimiliki masyarakat Desa Poreang, Kecamatan Tana Lili, Kabupaten Luwu Utara, Sulawesi Selatan belum didukung oleh kelembagaan ekonomi yang kuat baik dari segi manajemen, sumberdaya manusia, modal, maupun akses dalam menembus pasar. Berdasarkan hasil Podes tahun 2000, kelembagaan keuangan seperti bank dapat berfungsi sebagai lembaga pendukung permodalan (inklusi keuangan) bagi masyarakat pedesaan. Koperasi sebagai lembaga keuangan mikro ekonomi masyarakat tumbuh di semua kecamatan namun keberadaannya belum mampu bergerak sesuai kebutuhan masyarakat dan juga keberadaannya belum merata di semua desa.

Pengalaman masa lalu menunjukkan bahwa koperasi diandalkan sebagai penggerak perekonomian pedesaan. Koperasi Unit Desa (KUD) sebagai salah satu badan usaha yang banyak diharapkan dapat membantu terciptanya atau bangkitnya perekonomian masyarakat yang lebih baik. Akan tetapi, pada kenyataannya belum mampu diandalkan dan masih memperihatinkan (kurang sehat). Tidak efektifnya KUD disebabkan oleh bayak faktor, diantaranya yang menonjol: (a) kelemahan manajemen; (b) kelemahan sumberdaya manusia; (c) keterbatasan akses pendanaan dan modal; dan (d) kekurang mampu menembus pasar.

Bercermin pada permasalahan tersebut di atas, maka itupun yang terjadi pada kelembagaan yang ada di Desa Poreang. Kelembagaan yang mengakar pada masyarakat Desa Poreang, Kecamatan Tana Lili juga belum mampu berkembang, baik ditinjau dari aspek ekonomi maupun aspek sosial. Permasalahan yang dijumpai dari aspek ekonomi antara lain: (a) kurang berkembangnya sistem kelembagaan ekonomi untuk memberikan kesempatan dalam pengembangan kegiatan usaha ekonomi kompetitif; (b) kurangnya penciptaan akses 
masyarakat ke input sumberdaya ekonomi berupa permodalan (masalah inklusi keuangan), lokasi usaha, lahan usaha, informasi pasar, dan teknologi produksi; dan (c) lemahnya kemampuan masyarakat pedesaan untuk membangun organisasi ekonomi masyarakat.

Berbagai permasalahan tersebut di atas diharapkan dapat teratasi dengan hadirnya Badan Usaha Milik Desa (Bumdes) di setiap desa. Program ini dihadirkan sebagai motor penggerak ekonomi baru di desa demi menutupi kelemahan dari lembaga-lembaga ekonomi dan sosial yang ada di desa selama ini. Termasuk membangkitkan kembali energi bagi usaha-usaha yang ada selama ini di desa seperti KUD dan usaha-usaha produktif dari masyarakat desa setempat melalui pemberian bantuan dan pembinaan.

Peran Bumdes sangat diharapkan di pedesaan karena kawasan pedesaan memiliki peran yang penting dan strategis dalam mendukung pembangunan nasional. Kemandirian pembangunan kawasan pedesaan merupakan salah satu pendekatan dalam mendorong perkembangan ekonomi secara nasional dengan memanfaatkan potensi yang ada di wilayah pedesaan tersebut. Perkembangan ekonomi kawasan perdesaan diharapkan dapat mengurangi ketergantungan kawasan pedesaan terhadap kota dan menguatkan peran desa sebagai pusat produksi kebutuhan sumberdaya pembangunan.

Membangun hubungan keterkaitan antar desa-kota juga merupakan salah satu cara yang ditempuh sebagai suatu upaya pembangunan wilayah perdesaan, dimana peran desa dikuatkan sebagai pusat produksi dan sumberdaya. Pola tersebut diharapkan mendorong perkembangan ekonomi desa dan mendorong permerataan ekonomi antara desa dan kota. Untuk mengatasi permasalahan tersebut, diperlukan alternatif-alternatif baru dan introduksi ilmu pengetahuan yang bisa dilakukan terhadap pemberdayaan ekonomi masyarakat pedesaan. Melalui program KKN-PPM bersama mahasiswa dilakukan pembelajaran pemberdayaan masyarakat untuk memperbaiki kekurangan dan kelemahan serta metode dan cara tradisional yang selama ini dianut dan diyakini oleh masyarakat.

\section{Metode Pelaksanaan}

Metode pelaksanaan program KKN-PPM Pemberdayaan Ekonomi Masyarakat Desa Poreang, Kecamatan Tana Lili melalui Bumdes dilakukan dengan metode participatory rural appraisal (PRA) untuk mengatasi masalah strategis yang dihadapi dalam pemberdayaan ekonomi masyarakat, dengan tahapan:

a. Identifikasi Potensi, Permasalahan, dan Kebutuhan Masyarakat

Identifikasi potensi, permasalahan, dan kebutuahan pembangunan masyarakat meliputi 
identifikasi potensi pengembangan kelembagaan ekonomi masyarakat desa Poreang Kecamatan Tana Lili.

\section{b. Penyusunan Program Kerja}

Penyusunan program dilakukan dengan menerapkan participatory rural appraisal (PRA) yang berbasiskan pada potensi, permasalahan, dan kebutuhan masyarakat pedesaan yang memuat hal-hal seperti masalah, kegiatan, pelaksanaan, sasaran, metode waktu, penanggungjawab, dukungan program/proyek lain, dinas/instansi pendukung dan perkiraan biaya.

c. Evaluasi Penerapan Program

Evaluasi mencakup dua aspek yaitu evaluasi penerapan rencana kegiatan bersama masyarakat dan evaluasi penerapan kegiatan antara fasilitator dengan menggunakan indikator-indikator yang telah disepakati bersama.

Sebelum mahasiswa diberangkatkan ke lokasi sasaran yakni Desa Poreang, Kecamatan Tana Lili, terlebih dahulu mahasiswa diberi bekal pengetahuan dasar life skill. Sehingga ketika sudah berada di tengah-tengah masyarakat mahasiswa dengan mudah mentransfer ilmu yang telah didapatkan. Konsep yang akan digunakan dalam pengembangan Desa Poreang kecamatan Tana Lili melalui program Pembelajaran Pemberdayaan Masyarakat (PPM) adalah sebagai berikut:

a. Mempersiapkan masyarakat untuk berpartisipasi menumbuhkan rasa memiliki dan tanggungjawab terhadap program yang dilaksanakan.

b. Mengembangkan kemampuan masyarakat untuk mewujudkan dan mempengaruhi arah serta pelaksanaan satu program dengan mengandalkan kekuatan yang dimiliki masyarakat sehingga pemberdayaan merupakan tema sentral untuk menumbuhkan jiwa aktif dan kreatif masyarakatnya.

c. Pemberdayaan dalam kelembagaan Bumdes dengan memberdayakan keragaman aktivitas ekonomi (kelompok usaha) masyarakat dengan cara mengembangkan berbagai akses yang dapat mendukung pengembangan usaha seperti akses terhadap sumberdaya fisik; akses terhadap sumberdaya pembiayaan; dan akses terhadap kesempatan memperoleh pelatihan dan pendampingan usaha.

Bumdes dikelola oleh masyarakat desa secara profesional seperti halnya mengelola badan usaha lainnya. Sumber dana Bumdes dapat diperoleh dari berbagai sumber misalnya 
sumbangan dari kelompok usaha yang dikoordinir dalam bentuk balas jasa, pinjaman dari dana desa, bantuan dari lembaga donor serta aktivitas Bumdes lainnya, sehingga dalam membangun desa tidak tergantung dari anggaran kabupaten saja tetapi bisa menggunakan dana dari kas desa.

\section{Hasil dan Pembahasan}

Hasil dan luaran yang dicapai dalam penyelesaian masalah yang dihadapi dalam pemberdayaan masyarakat dengan metode penyelesaiannya, yang telah dikemukakan pada pada uraian sebelumnya melalui pelaksanaan progran Mahasiswa KKN-PPM Desa Poreang dilakukan selama kurang lebih 2 bulan adalah sebagai berikut:

a. KKN-PPM telah berhasil meyakinkan Kepala Desa dan BPD serta tokoh masyarakat Desa Poreang tentang pentingnya peran Bumdes dalam pemberdayaan masyarakat demi peningkatan Pendapatan Asli Desa (PAD) sebagai salah satu desa yang punya potensi ekonomi cukup besar, melalui sarasehan Bumdes yang dilakukan di Aula Kantor Desa Poreang yang dihadiri oleh Kepala Desa dan Aparatnya, Dosen Pembimbing, Ketua dan Anggota BPD, Tokoh Masyarakat, Tokoh Agama, Pendidik, Pemuda, Ketua dan Anggota Pengurus Bumdes serta Pendamping Desa.

b. KKN-PPM bersama pemerintah desa dan BPD melalui suatu pertemuan di kantor desa telah berhasil menyusun/memperbaiki PERDES tentang BUMDES Desa Poreang.

c. KKN-PPM bersama pemerintah desa dan BPD serta tokoh masyarakat melalui musyawarah telah berhasil memperbaharuhi kepengurusan BUMDES yang bisa bekerja lebih profesional dalam mengurus BUMDES Desa Poreang.

d. Dengan keyakinan yang ditanamkan oleh mahasiswa KKN-PPM tentang pentingnya penguatan fungsi BUMDES kepada Kepala Desa dengan persetujuan BPD melalui musyawarah telah ditetapkan alokasi dana dalam RPMJ Desa Poreang Tahun 2017 untuk BUMDES Desa Poreang sebesar Rp50 juta dan direncanakan pada tahun 2018 sebesar Rp100 juta.

e. Melalui kunjungan mahasiswa KKN-PPM ke dusun-dusun dalam wilayah kerja Desa Poreang sekaligus berdiskusi dengan Kepala Dusun setempat telah berhasil mengidentifikasi potensi ekonomi yang akan di kelola/dikembangkan oleh BUMDES di Desa Poreang. Hasil identifikasi tersebut dibawa ke dalam pertemuan untuk didiskusikan/dirapatkan dengan pemerintah desa, BPD dan pengurus BUMDES Desa Poreang sehingga disepakati membentuk kelompok usahanya, yakni: Usaha Simpan 
Pinjam, Usaha Budidaya Rumput Laut Katonik, Pengembangan Koperasi Petani Kelapa Sawit, Mitra Usaha Toko/Kios Serba Ada, Penyewaan Lapak-Lapak Tempat Berjualan setiap hari pasar di Pinggir Lapangan, Pengembangan Mitra Usaha Kripik Pisang dan Pemasarannya.

f. Demikian pula dengan keyakinan Kepala Desa terhadap penguatan ekonomi desa melalui BUMDES maka melalui saran sekaligus permintaan mahasiswa KKN-PPM hasilnya Kepala Desa menyiapkan kantor/sekretariat BUMDES Desa Poreang beserta fasilitas yang dibutuhkan di dalamnya, termasuk gambar struktural pengurus dan papan nama sekretariat.

g. Guna efektifitas dan efesiensi dalam pengelolaan BUMDES Desa Poreang, maka mahasiswa KKN-PPM juga bersama pengurus BUMDES menyusun/membuat seluruh dokumen yang diperlukan seperti administrasi umum dan administrasi keuangan BUMDES Desa Poreang melalui seminar tata kelola Bumdes.

Secara khusus mahasiswa KKN-PPM telah berhasil membantu menyusun laporan administrasi desa dan laporan keuangan BUMDES Desa Poreang. Selain itu, hasil yang paling menonjol dan fundamental dari KKN-PPM di Desa Poreang melalui pembentukan Usaha Simpan Pinjam dan sejumlah kelompok mitra usaha lainnya adalah keberhasilan menyerap tenaga kerja yang cukup lumayan dan kegairahan para mitra usaha untuk lebih mengembangkan usahanya.

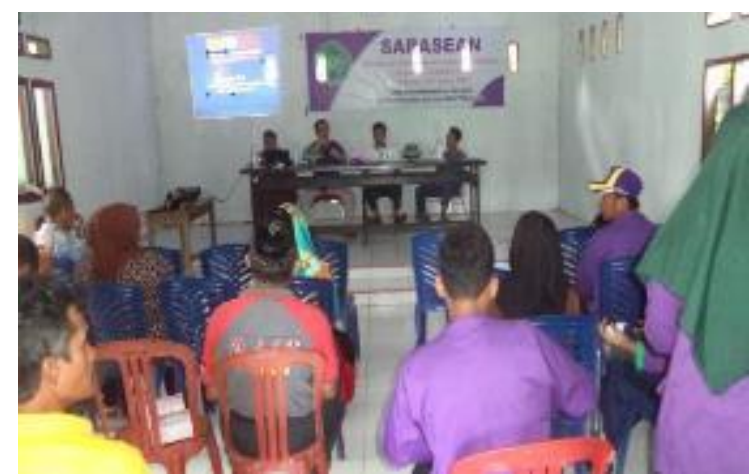

Gambar 1. Kegiatan Sarasehan

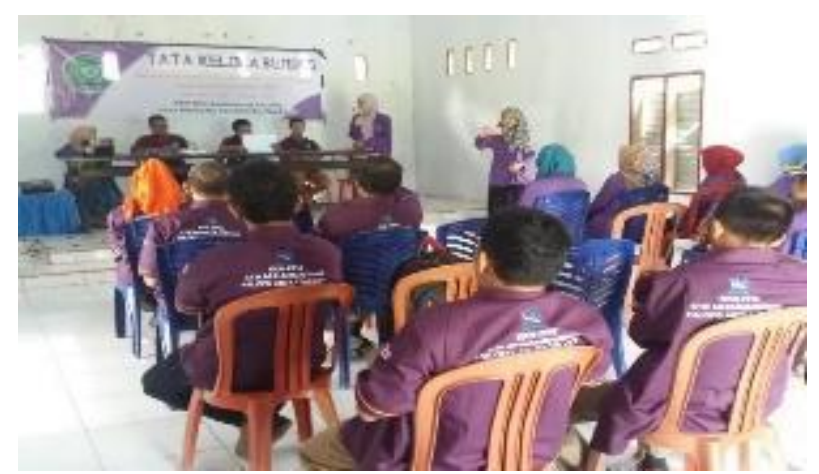

Gambar 2. Kegiatan Seminar Bumdes

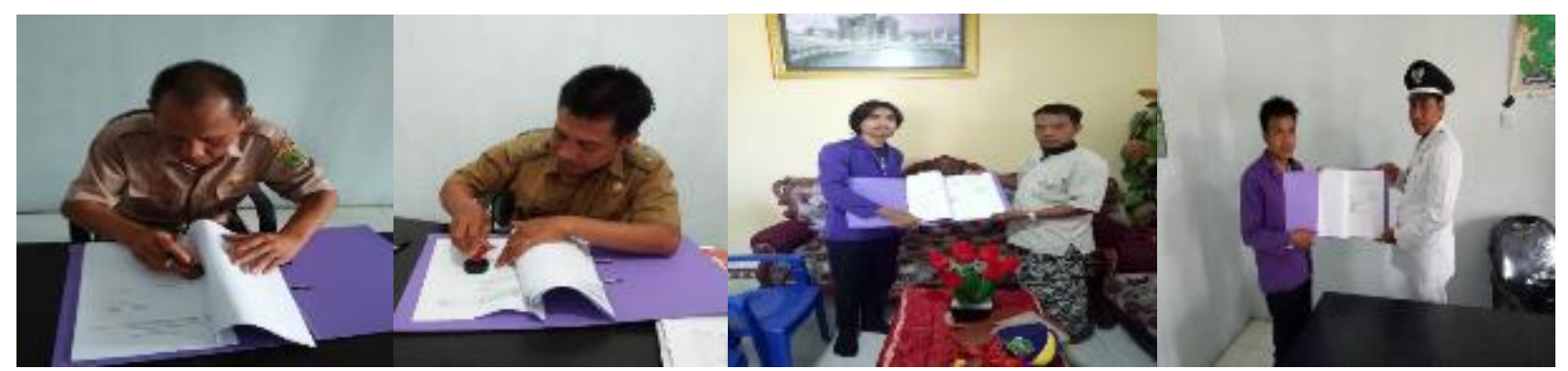

Gambar 3. Kegiatan Pengesahan Kontrak Kerjasama 


\section{Simpulan dan Saran}

Program KKN-PPM telah menjadi wadah yang lebih efektif dalam rangka mewujudkan Catur Dharma perguruan tinggi di STIE Muhammadiyah Palopo khususnya dalam rangka pemberdayaan ekonomi masyarakat. Terlihat dengan jelas bahwa melalui rogram KKN-PPM STIE Muhammadiyah Palopo di Desa Poreang. Pendekatan yang dilakukan oleh mahasiswa melalui kegiatan seminar, pelatihan/pembimbingan, kunjungan ke tokoh masyarakat, pemuda dan remaja terutama silaturrahim yang baik dengan pemerintah desa maka terbenahilah manajemen Bumdes yang baik, bersemangat dan lebih profesional sebagai ujung tombak dalam penguatan ekonomi desa. Sehingga terbentuklah beberapa kelompok usaha jasa dan produktif yang lebih bersemangat, yakni Usaha Simpan Pinjam, Usaha Kripik Pisang, Mitra Usaha Toko Serba Ada, Usaha Persewaan Lapak-Lapak Penjualan, Kelompok Usaha Rumput Laut Katonik, dan Koperasi Petani Kelapa Sawit. Kelompok usaha ini menjadi wadah penyerap tenaga kerja.

Disarankan agar STIE Muhammadiyah Palopo dan pemerintah desa, kecamatan dan kabupaten bisa dan tetap dapat mendukung terlaksananya program-program selanjutnya. Sehingga apa yang telah dihasilkan pada program KKN-PPM tersebut betul-betul dapat lebih dikembangkan di masa akan datang serta menjadi contoh yang lebih baik dan positif bagi daerah lain.

\section{Daftar Pustaka}

Arsyad, L. 1999. Pengantar Perencanaan dan Pembangunan Ekonomi Daerah. Yogyakarta: PT. BPFE Yogyakarta.

Dharmawan, A.H. 2002. Pengembangan Komunitas dan Pedesaan Berkelanjutan. Bogor: Institut Pertanian Bogor.

Robiati. 2003. Pemberdayaan Ekonomi Masyarakat Pedesaan Melalui Bumdes, Kajian Desa Bantan Air Kecamatan Bantan Kabupaten Bengkalis. Tesis. Program Pascasarjana Institut Pertanian Bogor.

Djohan, A. 1996. Pemberdayaan Masyarakat dan potensi Daerah Dalam Upaya Memacu Laju Pembangunan Daerah Menyongsong Otonomi Daerah yang Nyata dan Dinamis, Serasi dan Bertanggungjawab di Kabupaten Daerah Tingkat II Bengkalis. Lokakarya Pembangunan Daerah Kabupaten Bengkalis. (Disampaikan pada 24 Desember 1996) 